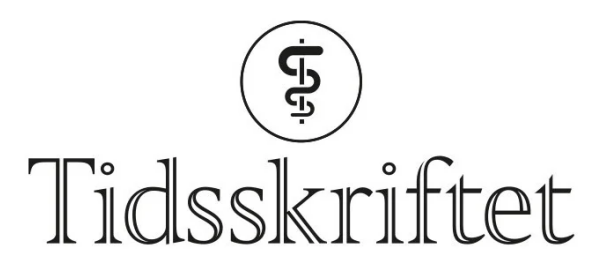

DEN NORSKE LEGEFORENING

\title{
Verdens beste utfordring
}

\author{
MINILEDER
}

ARE BREAN

Sjefredaktør

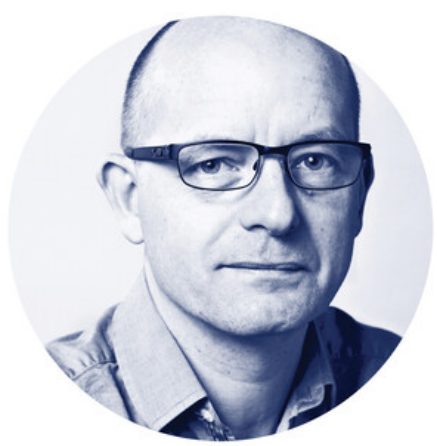

Litt i skyggen av valgkampen ble det norske helsevesenet i august 2021 kåret til verdens beste. Det er The Commonwealth Fund som rangerer elleve av verdens helsevesen $\mathrm{i}$ henhold til kriteriene tilgang, behandling, effektivitet, rettferdighet og resultater. I 2014 kom Norge på syvendeplass, i 2017 på fjerdeplass og i år altså på førsteplass, fulgt av Nederland og Australia. Aller best gjør Norge det på kriteriet effektivitet. Gode primærhelsetjenester fremheves som den viktigste grunnen til dette. Dårligst gjør vi det på rettferdighet, som måler forskjellen i tilgangen til helsetjenester mellom inntektsgrupper.

Klatringen på denne kåringen har skjedd på Bent Høies vakt som helseminister. Det vil han bli husket for. Nå overtar en ny regjering og en ny helseminister ansvaret. Det vil ikke bli lett. Forventningene i befolkningen er skyhøye. Utfordringene i verdens beste helsevesen står i kø. Men først og fremst er det mer å redde enn å nyskape. Å redde fastlegeordningen haster aller mest, har Arbeiderpartiets Ingvild Kjerkol uttalt. Det er en fornuftig prioritering. Fastlegeordningen er grunnfjellet som både et effektivt og et rettferdig helsevesen står på.

Publisert: 27. september 2021. Tidsskr Nor Legeforen. DOI: 10.4045/tidsskr.21.13.01

(C) Tidsskrift for Den norske legeforening 2023. Lastet ned fra tidsskriftet.no 26. april 2023. 